EESTI NSV TEADUSTE AKADEEMIA TOIMETISED. XI KOIDE FOOSIKALIS-MATEMAATILISTE JA TEHNILISTE TEADUSTE SEERIA. 1962, NR. 2

ИЗВЕСТИЯ АКАДЕМИИ НАУК ЭСТОНСКОИ ССР. ТОМ ХІ СЕРИЯ ФИЗИКО-МАТЕМАТИЧЕСКИХ И ТЕХНИЧЕСКИХ НАУК, 1962, № 2

\title{
ЗАКОНОМЕРНОСТИ РАСПРЕДЕЛЕНИЯ ГАЛЕК В МОРЕНАХ ЭСТОНИИ
}

\section{A. РАУКАС}

13 последние годы в Эстонской ССР при изучении моренных отложений достиг нуты значительные успехи. Особого внимания здесь заслуживает статья К. Қ. Орви ку [1'], где впервые прнводятся сводные данные о литологии морен республики. В Ннституте геологии АН ЭССР начато детальное изучение минералогического состава морен и ряда другнх проблем, связанных с моренами. Сюда относится и вопрос ө закономерности распределения галек в моренах, рассмотрению которого посвящено настоящее сообщение.

\section{Методика исследования}

ІІри полевых работах использовался так называемый объемный метод исследования, общие принципы которого мало отличаются от метода, предлагаемого C. В Яковлевой $[10-12]$, и который обладает рядом достоннств по сравнению с другими методами. Были огределены гранулометрический и петрографический составы, количество, форма и окатанность галек, а также ориентировка их длинных осей. Для осуществления всего этого комплекса наблюдений в невыветрелой части морены была вырыта̀ выемка объемом $0,02-0,25 \mathrm{~m}^{3}$ (объем зависит от содержания галек). Из последней выбирались все гальки*, причем ориентировка длинных осей продолговатых галек замерялась заранее при помощи горного компаса. Қ. Рихтер [7], С, В. Яковлева $\left[{ }^{10-12}\right]$ и некоторые другие исследователи считают, что число замеров ориентировки на одной расчистке должно быть не менее 50 , а для получения более точных данных - около 100. По наблюдениям автора, достаточно замерить 30-40 галек, так как дальнейшее увеличение числа замеров не дает существенных изменений при трафическом выражении результатов.

Собранные гальки подвергались ситовому анализу, с разделением на фракции $1-2,2-4,4-6$ и 6-10 см. Для всех фракций при помощи переливного сосуда был определен средний объем галек, а на основе этого - процентное содержание всей галечниковой фракции и количество галек в 1 м $^{3}$ морены. Для каждой фракции были выяснены также количественные соотношения галек пяти групп пород, имеющих наибольшее распространение в местных условиях [14]: 1) кристаллические (магматические и метаморфические), 2) карбонатные ордовика и силура, 3) кембрийские, 4) девонские и 5) остальные. Для более точного определения различных типов кри-

* K галечниковой фракции отнесены обломки пород, проходившие через сито с отверстиями $\varnothing 10 \mathrm{~cm}$. но оставшиеся на сите с отверстиями $\varnothing 1 \mathrm{~cm}$, т. е. обломки пород диаметром от 1 до $10 \mathrm{~cm}$. 
сталлических пород из всего обнажения или горизонта морены собирали 100-200 галек диаметром 4-10 см. Особое внимание уделяли сбору руководящих типов. Форму и окатанность галек определяли для местных пород на основе материала объемного анализа во фракции 2-10 см, а для кристаллических пород - во фракции 4-10 см. Обычно просматривали 100-200 галек. Из каждого обнажения брали образцы морены для определения цвета, карбонатности, минералогического состава и других свойств, которые изучались в лабораторных условиях обычными литолого-минералогическими методами. Всего выполнено 211 объемных анализов из 195 местонахождений. На выходах ордовикских и силурнйских пород расположено 102 анализа, на выходах девонских пород - 104 и перед глинтом -5.

\section{Количество галек в морене}

Қоличество галек в моренах Эстонии (за исключением локальных морен) колеблется в больших пределах '(фиг. 1). В некоторых обнажениях (Куриста, Янтра, Савала и Кахула) их в 1 м меньше 1000, в то время как в других (Ойтме, Кали, Уула) количество их в $1 \mathrm{~m}^{3}$ превышает 35000 . В большинстве случаев (70\% всех анализов) количество галек в 1 м $^{3}$ морены колеблется в пределах от 1000 до 15000 ,

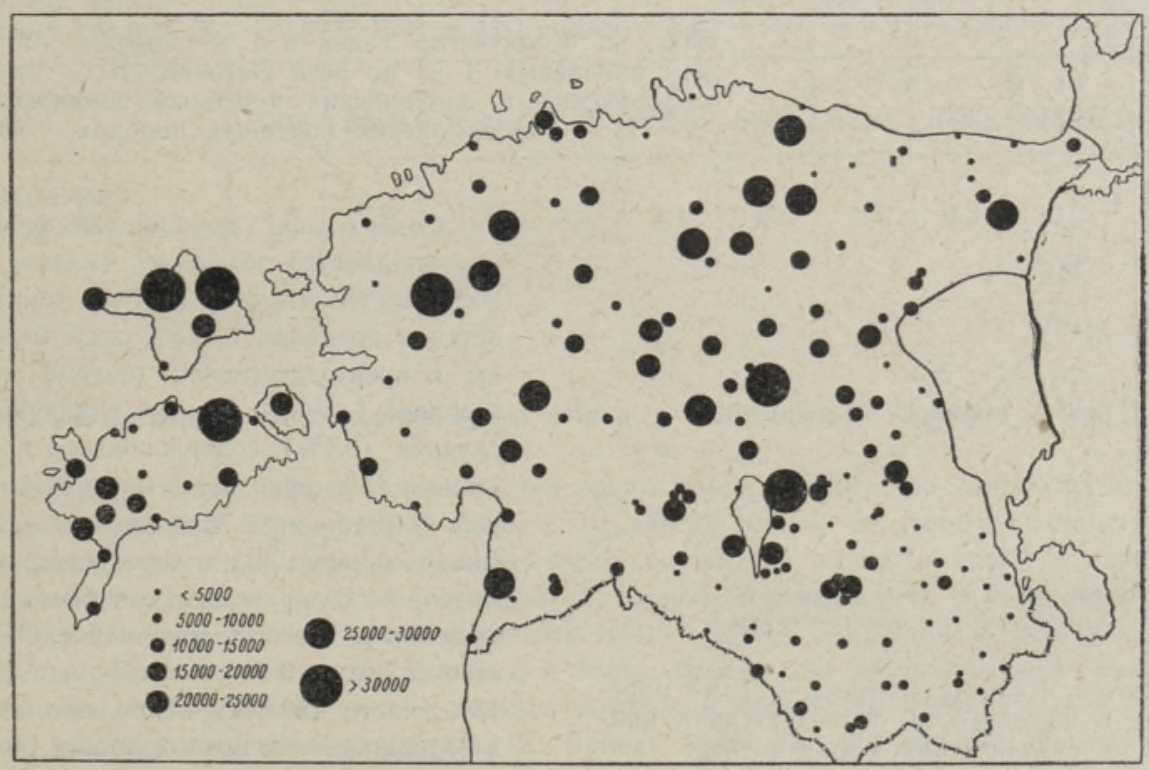

Фиг. 1. Количество галек в $1 \mathrm{~m}^{3}$ морены.

в $30,5 \%$ случаях - в пределах 5000-10000. Морены, залегающие на силурийских и ордовикских карбонатных породах, обычно содержат значительно больше галек, чем морены, залегающие на девонских песчаниках (фиг. 2). Таких местонахождений, где в 1 м ${ }^{3}$ менее 15000 галек, в южной Эстонии $85,5 \%$, в северной - 62,3\%; местонахождений, где галек больше 25000 , в северной Эстонии $14,1 \%$, а в южной - лишь $3,9 \%$. Это легко объясняется влиянием подстилающих коренных пород. Так, при движении по североэстонским карбонатным породам морена непрерывно обогащалась достаточно прочными к истиранию известняками и доломитами. В южной Эстонии это обогащение в основном прекратилось, так как девонские песчаники недостаточно гверды, чтобы значительно обогатить морену гальками $\left[{ }^{14}\right]$. 
Поскольку кристаллические породы более устойчивы к истиранию, чем карбонатные, в южноэстонских моренах пронсходит относительное обогащение ими.

Таким образом, подтверждается интересная закономерность, отмеченная еще В. Петерселлем*: чем больше в морене галек кристаллических пород, тем меньше в ней галек, или, чем больше в морене карбонатных пород, тем больше в ней и галек. По нашим материалам эта зависимость графическн представлена на фиг. 3.
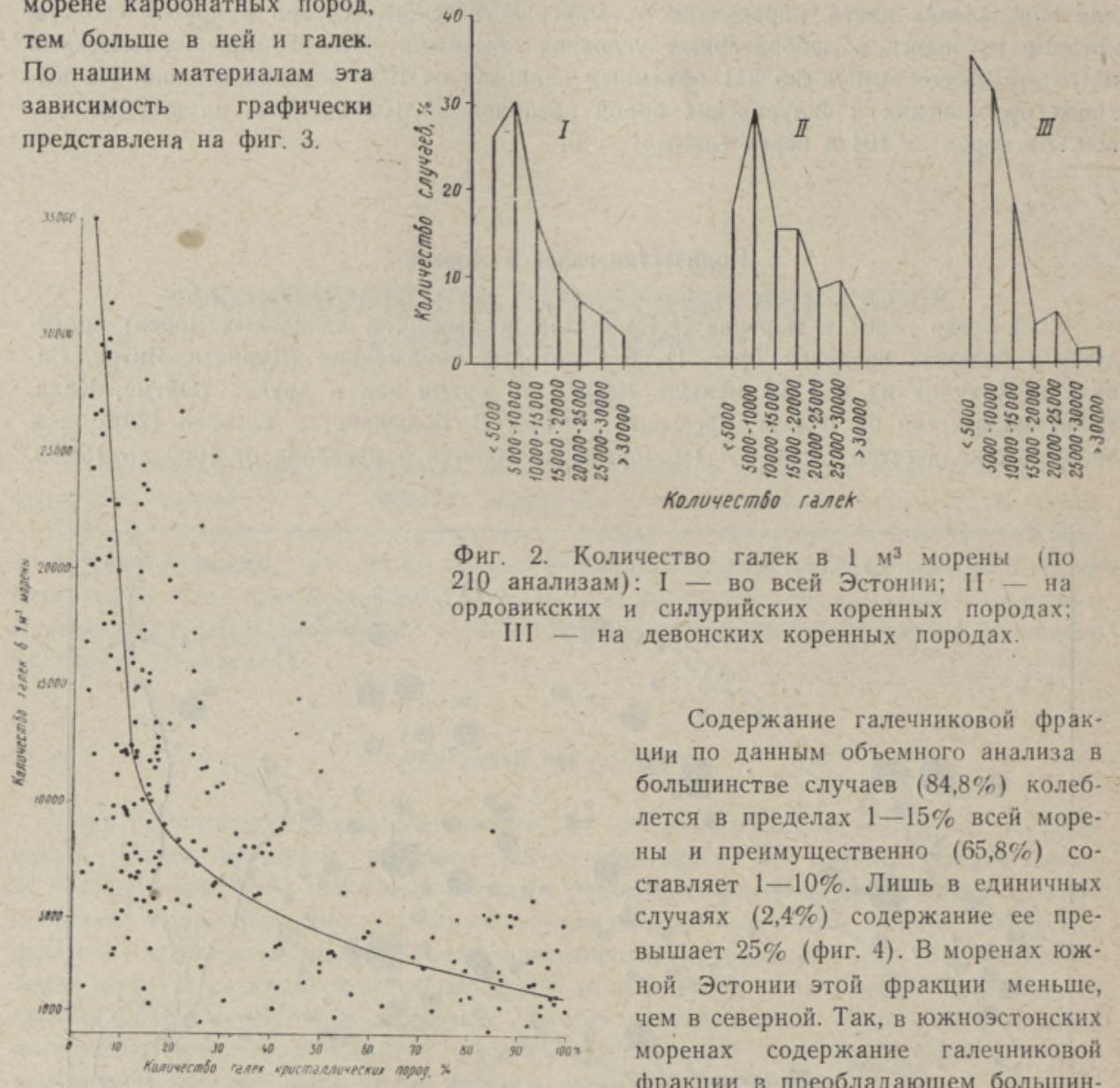

Kоличест6о raлek

Фиг. 2. Количество галек в $1 \mathrm{~m}^{3}$ морены (по 210 анализам): I - во всей Эстонни; II - на рдовикских и силурийских коренных породах; II - на девонских коренных породах.

Содержание галечниковой фракции по данным объемного анализа в большинстве случаев $(84,8 \%)$ колеблется в пределах $1-15 \%$ всей морены и преимущественно $(65,8 \%)$ составляет $1-10 \%$. Лишь в единичных случаях $(2,4 \%)$ содержание ее превышает $25 \%$ (фиг. 4). В моренах южной Әстонии этой фракции меньше, чем в северной. Так, в южноэстонских моренах содержание галечниковой фракции в преобладающем большин-

Фиг. 3. Количество галек в $1 \mathrm{~m}^{3}$ морены в зависимости от содержания кристве случаев $(98,0 \%)$ составляет 0 $15 \%$, часто $(59,6 \%)$ не больше $5 \%$, сталлических пород в ней.

а содержание ее, превышающее $15 \%$, наблюдается лишь в редких случаях. В североэстонских моренах содержание галечниковой фракции, превышающее $15 \%$, отмечается в $19,9 \%$ случаях. Эти данные хорошо совпадают с результатами К. Орвику [14], полученными рамковым анализом.

Количество галек и содержание галечниковой фракции в пределах одного обнажения морены как в вертикальном, так и в горизонтальном разрезе довольно постоянны. Для иллюстрации приводим результаты некоторых серийных анализов (табл. 1).

Утверждение К. Кильдема [4] о том, что в моренах северной Эстонии количество галек с увеличеннем глубины обычно возрастает, а в моренах южной Эстонии уменьшается, нашими данными не подтверждается.

* V. Petersell, Moreenidest Eesti NSV kagurajoonides. Дипломная работа, 1957. Рукопись в фондах геологического отделения Тартуского гос. ун-та. 
Фиг. 4. Содержание галечниковой фракции в моренах (по 210 анализам): I - всей Эстонии; II - на ордовикских и силурийских коренных породах; III - на девонских коренных породах.

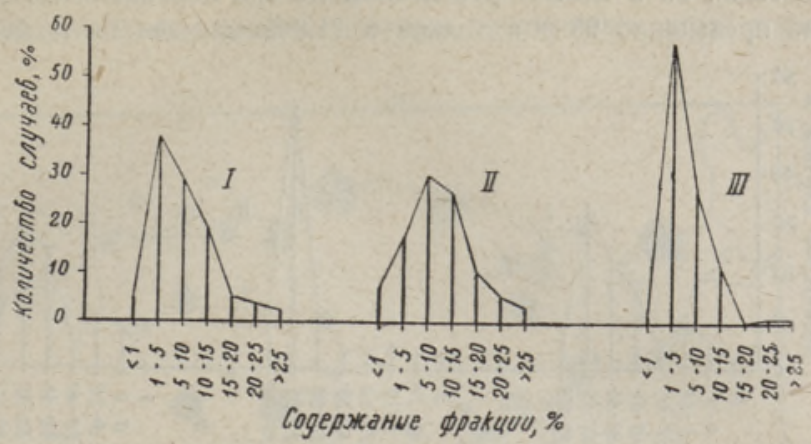

Таблица 1

\begin{tabular}{|c|c|c|c|c|c|c|c|c|c|c|}
\hline $\begin{array}{c}\text { Место } \\
\text { обнажения }\end{array}$ & \multicolumn{2}{|c|}{ Реола } & \multicolumn{2}{|c|}{ Онтика } & \multicolumn{2}{|c|}{ ГІяртлиорг } & \multicolumn{2}{|c|}{ Кабала } & \multicolumn{2}{|c|}{ Отепя } \\
\hline $\begin{array}{l}\text { Расстояние меж- } \\
\text { ду выемками, м }\end{array}$ & & 0 & & 55 & & 0 & & 0 & & 4 \\
\hline $\begin{array}{l}\text { Глубина выпол- } \\
\text { нения анализа, м }\end{array}$ & $|0,2-\overline{5}|$ & $\mid 0,5-\overline{-0,9}$ & $\frac{2,3-}{-2,5}$ & $\frac{2,3-\overline{-}}{-2,5}$ & $\mid \frac{1,1-1,4}{-1,4}$ & $\left|\frac{1,7-}{-2,0}\right|$ & $\frac{0,5-\overline{9}}{-0,9}$ & $1,0-\overline{1,5}$ & $\frac{0,8-\overline{2}}{-1,2}$ & $\mid 0,7-1,1$ \\
\hline $\begin{array}{l}\text { Количество га- } \\
\text { лек }\end{array}$ & 6000 & 5500 & 1680 & 1485 & 8950 & 8800 & 4750 & 3350 & 22800 & 24200 \\
\hline $\begin{array}{l}\text { Содержание } \\
\text { фракции, \% }\end{array}$ & 4,0 & 3,9 & 1,7 & 0,9 & 3,4 & 5,2 & 2,8 & 2,3 & 13,2 & 13,2 \\
\hline
\end{tabular}

\section{Количественное соотношение групп пород в галечниковой фракции морен *}

Впервые количественное соотношение групп пород в галечнике эстонских морен было изучено К. К. Орвику [14]. В связи с тем, что до тех пор соответствующие данные совершенно отсутствовали и необходимо было получить их в сжатые сроки, К. Орвику применил быстрый и удобный рамковый метод исследования, хотя и было известно, что нзучение небольшого количества галек может иногда приводить к значительным ошибкам. Большее количество анализов и более совершенная методика дали нам возможность получить более точные данные, которые и излагаются ниже. Следует отметить, что расхождения в результатах К. Орвику и автора частично обусловлены еще различиями в исследованных размерных фракциях (К. Орвику включил в галечниковую фракцию обломки размером свыше 20 мм).

Қоличественное соотношение различных групп пород отличается в моренах южной и северной Эстонии, что легко объясняется влиянием подстилающих коренных пород. Морены северной Эстонии, расположенные на коренных выходах ордовика и силура. содержат в своей галечниковой фракции значительно больше карбонатных и меньше кристаллических пород, чем морены южной Эстонии. Так, в моренах северной Эстонии в $55,6 \%$ случаев содержание карбонатных пород колеблется в этой фракции в пределах $80-95 \%$ и в $12,4 \%$ случаев даже превышает $95 \%$, тогда как в моренах южной

* При составленик настоящей главы кроме материалов автора использованы также данные из вы:шеуказанной рукописной работы В. Петерселля. Выводы базируются на 277 объемных анализах. 
Эстонии ни в одном проведенном до сих пор анализе содержание карбонатных пород не превышало $95 \%$ и только в $21,8 \%$ случаев было больше $80 \%$.

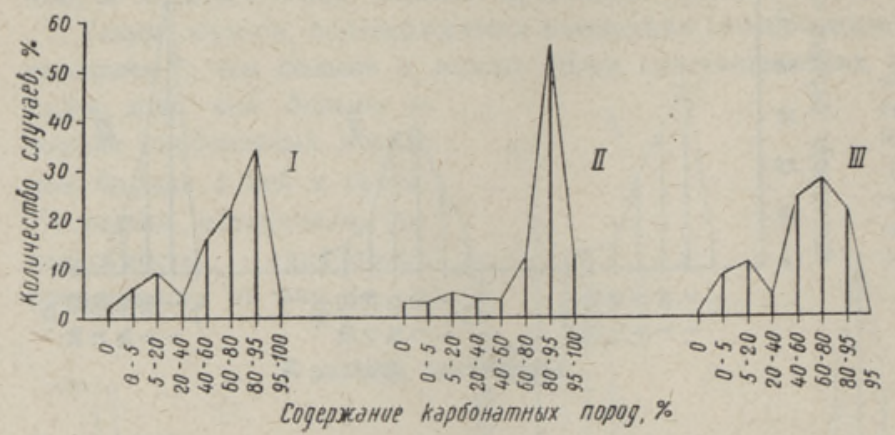

Фиг. 5. Содержание карбонатных пород в галечниковой фракции морен (по 277 анализам): I всей Эстонии; II - на ордовикских и силурийских коренных породах; III - на девонских коренных породах.

Фиг. 6. Содержание кристаллических (магматических и метаморфических) пород в галечниковой фракции морен (по 277 анализам): I - всей Эстонии; II - на ордовикских и силурнйских коренных породах; III - на девонских коренных породах.

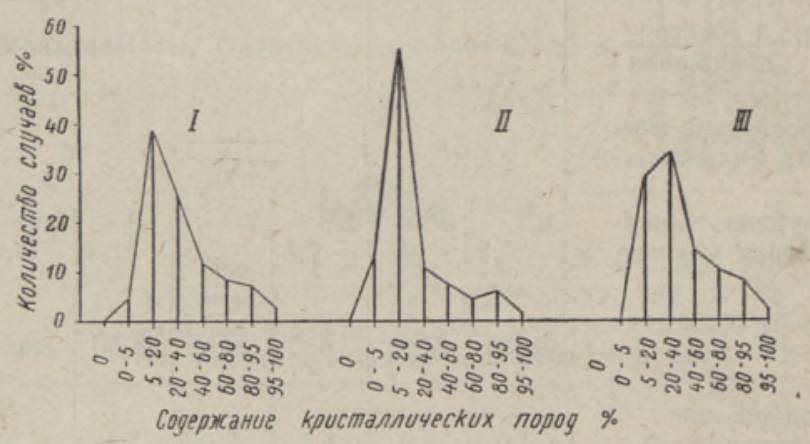

С другой стороны, в моренах южной Эстонии ни в одном выполненном нами анализе содержание кристаллических пород не было меньше $5 \%$ и лишь в $29,2 \%$. случаев количество этих пород не превышало $20 \%$. В то же время в моренах северной Эстонии содержание кристаллических пород меньше $5 \%$ наблюдалось в $12,8 \%$ случаев, меньше $20 \%$ - в $68,7 \%$. случаев.

Кроме вышеуказанных, морены южной Эстонии содержат гальки девонских песчаников (среднее содержание $3,9 \%$ ), отсутствующие в моренах северной Өстонии.

Таблица 2

\begin{tabular}{l|c|c|c}
\hline \multirow{1}{*}{ Место } & \multicolumn{3}{|c}{ Породы, \% } \\
\cline { 2 - 3 } & $\begin{array}{c}\text { кристалличе- } \\
\text { ские }\end{array}$ & карбонатные & $\begin{array}{c}\text { песчаники и } \\
\text { сланцы кемб- } \\
\text { рия и нижнего } \\
\text { ордовика }\end{array}$ \\
\hline Силлаотса & 98,5 & - & 1,5 \\
Карепа & 98,5 & - & 1,5 \\
Меривялья & 23,3 & 54,1 & 22,6 \\
Вяэна-Йэсуу & 26,5 & 48,7 & 24,8
\end{tabular}

Соотношение различных групп пород отличается также в моренах западной и восточной Әстонии (фиг. 7). Морены восточной Эстонии беднее гальками карбонатных и богаче гальками кристаллических пород, чем морены западной Эстонии. Так, среднее содержание карбонатных пород в моренах восточной Эстонии составляет $55,6 \%$ против $76,0 \%$ в западной, а количество кристаллических пород - соответственно $39,6 \%$ против $20,8 \%$. 
В литературе до сих пор мало данных о соотношении различных групп пород в предглинтовых моренах Эстонии. В большинстве случаев среди галек этих морен

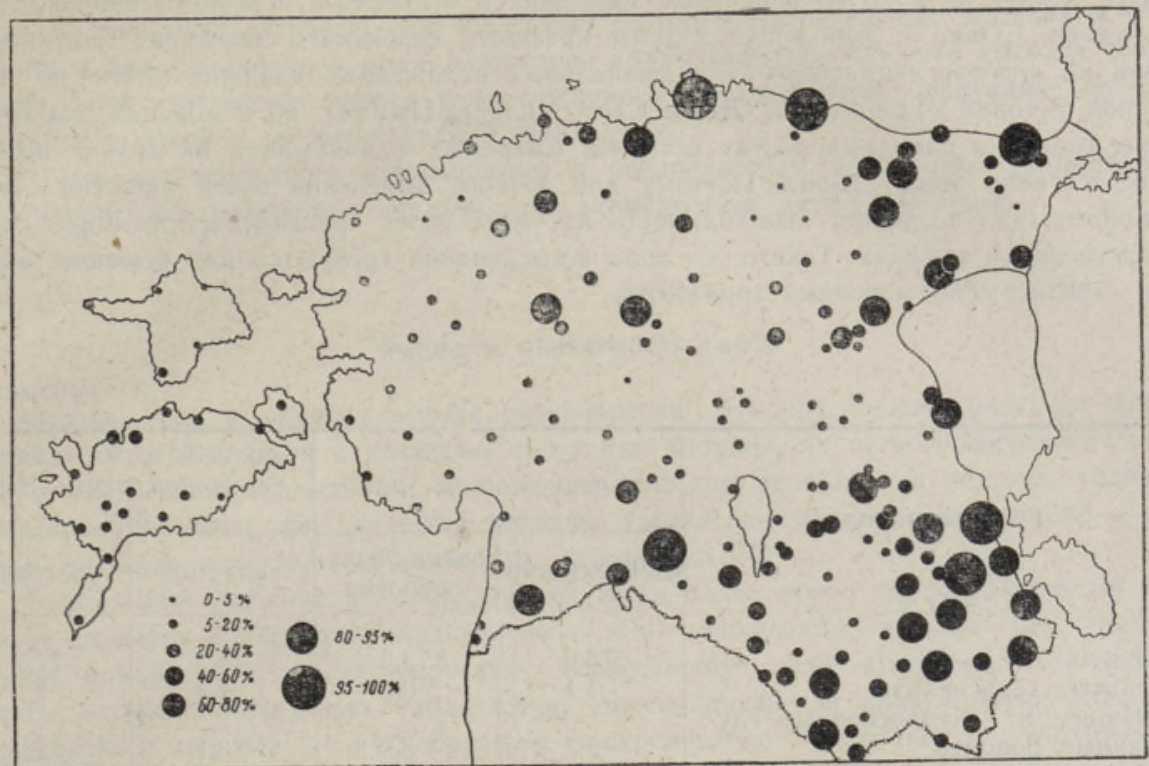

Фиг. 7. Количество кристаллических (магматических и метаморфических) пород в галечниковой фракции морен Эстонии (в \%).

отсутствуют карбонатные породы и галечниковая фракция их состоит только из кристаллических $\left[{ }^{15}\right]$ или кристаллических и кембрийских пород, иногда с примесью песчаников или сланцев нижнего ордовика (пакерортский и лээтсеский горизонты). Но в некоторых обнажениях предглинтовые морены содержат много галек карбонатных пород (Маарду, Меривялья, Вяэна-Ныэсуу и др.), что обусловлено влиянием глинта или карбонатных останцев к северу от глинта. Так, в меривяльяскую морену гальки известняков могут быть принесены с полуострова Виймси, в вяэна-йыэсуускую морену из тюрисалуского клиффа и т. д. В табл. 2 приводятся данные о соотношении групп пород в некоторых предглинтовых моренах республики.

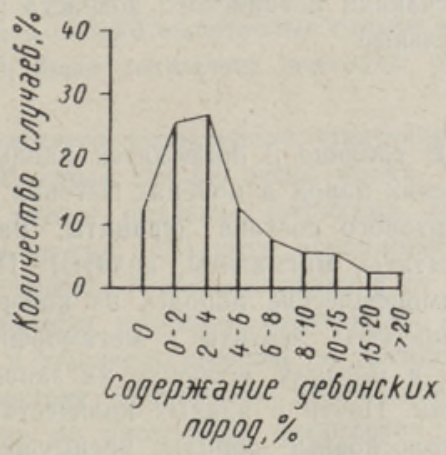

Фиг, 8. Содержание девонских пород в галечниковой фракции морен южной Эстонии (по 178 анализам).

\section{Распределение различных групп галек кристаллических пород}

В моренах Эстонии встречаются почти все основные группы кристаллических пород, начиная от кислых и кончая ультраосновными. Исходной областью их служат, в основном; Южная Финляндия и дно Балтийского моря. Шведские породы обнаружены лишь в немногих случаях среди прибрежной гальки на западном берегу западных островов республики.

Детальнье исследования кристаллических валунов Эстонии были проведены Х. Вийдингом $\left[{ }^{9,18}\right]$. Им дано петрографическое описание и приведены процентные соотношения для всех имеющихся на территории республики типов валунов, выделен ряд 
руководящих типов с указанием ареалов их распространения и т. д. На основе нзучения кристаллическнх валунов сделан ряд ценных палеогеографических выводов.

X. Вийдинг занимался в основном изучением поверхностных валунов, которые могут лежать не в своем первичном залегании в отношении моренного покрова. Так. напрнмер, гальки и небольшие валуны красного кварцевого порфира Балтиїского моря во флювиогляциальных и аллювиальных отложениях найдены почти во всей южной Эстонии (Таэваскода, Отепя, Сару, Килинги-Нымме), но в моренах они встречены только в западных частях островов Сааремаа и Хийумаа и на других неболь пих островах этого района. Поэтому для точного выяснения путей движения материкового льда возникает необходимость изучения галек кристаллических пород непосредственно в моренах. Такого же рода исследования требуются для решения вопросов стратиграфии моренных горизонтов.

Таблица 3

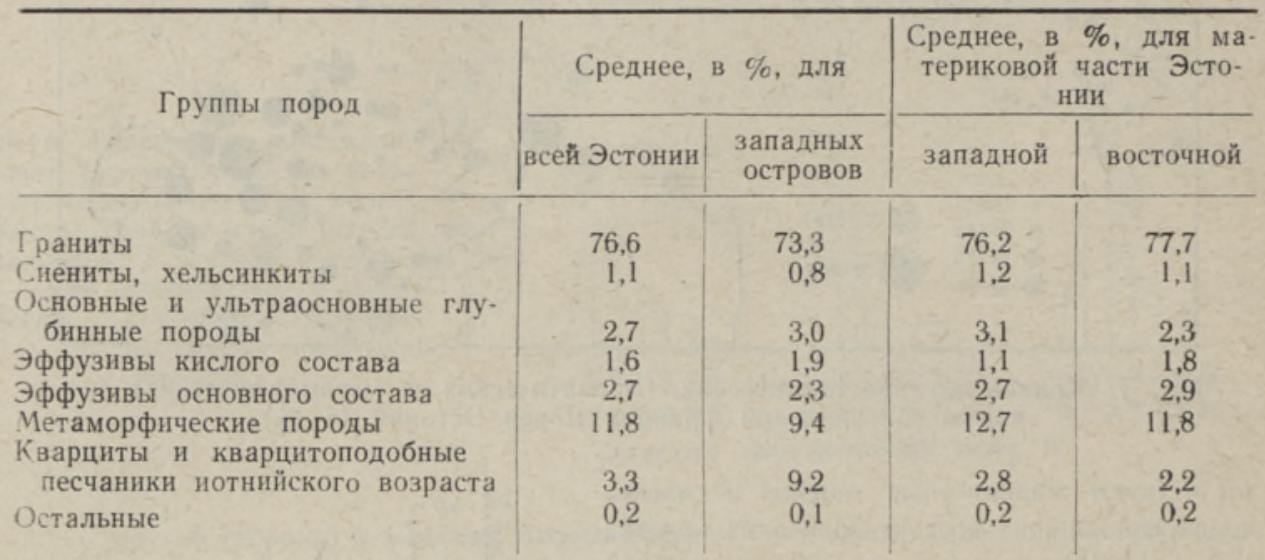

В таблице 3 приводятся данные о количественных соотношениях галек кристалличе́ских пород в моренах Эстонии. Как видно из таблицы, здесь преобладают породы гранитового состава (граниты, рапакиви-граниты, рапакиви, порфировые граниты, пегматиты, мигматиты, аплиты). По количественному содержанию за ними следуют метаморфические породы, из которых чаще всего встречаются разные гнейсы, реже амфиболиты, лептиты и метаморфические сланцы. Относительно широко распространены в моренах, особенно на западных островах, иотнийские кварцитоподобные песчаники. Почти в равных количествах наблюдаются породы групп диорита и габбро. Ультраосновные породы, преимущественно пироксениты, обнаружены лишь в виде единичных находок. Основные разновидности эффузивных пород (диабазы, диабазовые порфириты, уралитовые порфириты, плагиоклазовые порфириты и др.) встречаются чаще, чем кислые (кварцевые порфиры, фельзиты, фельзит-порфиры).

Сравнение результатов автора с данными, полученными Х. Вийдингом $\left[{ }^{18}\right]$ для поверхностных кристаллических валунов, показывает их неплохое совпадение. Имеющиеся расхождения объясняются, главным образом, различиями в исследованных фракциях. В галечниковой фракции, например, увеличивается содержание эффузив. ных пород, кварцитов и кварцитоподобных песчаников, которые либо захватываются ледником в виде небольших валунов, либо легко распадаются и окатываются в нем благодаря своей хрупкости или небольшой прочности. Относительным накоплением в галечниковой фракции эффузивов основного состава объясняется и полученное автором большее содержание группы основных пород по сравнению с результатами Х. Вийдинга, Труднее всего поддаются объяснению значительные расхождения в содержании метаморфических пород на западных островах и в западных частях материковой части республики. 
Выделить какие-либо закономерности в распределении различных групп кристаллических пород на основе вычисленных средних данных оказывается невозможным из-за равномерного распределения этих групп по всей территории республики. Исключение составляет высокое содержание кварцитоподобных песчаников иотннйского возраста на западных островах, обусловленное влиянием Сатакунтского массива в Финляндии и дна Балтийского моря. Последнее подтверждается тем, что высокие содержания этих песчаников всегда сопровождаются руководящими валунами со дна Балтийского моря и из юго-западной Финляндии.

Ясные закономерности наблюдаются в распределении в моренах руководящих валунов, но эти материалы автором еше окончательно не разработаны.

\section{Форма и окатанность галек}

Форма галек в моренах весьма разнообразна. Это обусловлено разными причинамн: первичной формой и размером галек или валунов, их петрографическим составом и физическими свойствами, местом и характером залегания в леднике, условиями гляциалмеханики при движении ледника, характером подстилающих пород и степенью насыщенности ледника моренным материалом [17].

Нанбольшее значение для образования форм галек имеют петрографический состав и характер слоистости, сланцеватости или отдельности породы. Так, граниты обычно приобретают овально-округлую, бесформенную или асимметричную форму; гнейсы - овально-округлую, таблитчатую, дисковидную или клиновидную; порфиры, порфириты и мергели - яйцеобразную, тонкослоистые известнякн - таблитчатую и т. д. Немалое значение для образования формы имеет выветривание обломков, которое вызывает распад крупных валунов и галек на бесформенные остроугольные обломки различного размера. Наиболее сильному выветриванию подвергаются гнейсы, крупнозернистые граниты и граниты рапакиви. Нередко в одном и том же обнажении можно увидеть рядом совсем не выветрелые и сильно выветрелые гальки одних и тех же типов пород. По всей вероятности, они были захвачены ледником уже в различных стадиях выветривания.

Для валунов и галек, переносимых льдом, считается характерной утюгообразная форма. Но в моренах Эстонии типичные утюгообразные гальки очень редки. Чаще здесь встречаются гальки со штрихами. Больше других покрыты штрихами гальки известняков, которые ввиду своей мягкости лучше других поддаются исцарапыванию.

Окатанность галек зависит от длительности и способа транспортировки и от литолого-петрографического состава и степени выветрелости исходного материала. Быстрее других окатываются гальки диктионемового и горючего сланцев и песчаников, затем карбонатных пород. Лучше других противостоят окатыванию кристаллические породы. Так, обломки диктионемового сланца уже на расстоянии неспольких километров от коренных выходов сланца идеально окатаны, а на расстоянии нескольких десятков километров почти полностью истираются и исчезают из галечниковой фрак. цни. Поэтому возникает необходимость вычисления коэффициентов окатанности отдельно для разных групп пород*. Но и здесь возникают трудности, так как, например, из карбонатных пород мергелистые разновидности окатываются значительно быстрее, чем известняки и доломиты и т. д. Необходимо также принимать во внимание, что морену образует не только материал нижележащих коренных пород, но и материал более древних плейстоценовых '(моренных, флювиогляциальных, аллювиальных, морскнх) отложений, в которых уже имеются более или менее окатанные гальки и которые могут вызывать локальные максимумы коэффициентов окатанности. В мо-

* Для определения коэффнциента окатанности автором применена пятибальная система: 0 - гальки с острыми ребрами и углами, 1 - угловатые гальки со слабоокатанными ребрами и углами, 2 - гальки со среднеокатанными ребрами и углами, 3 - гальки с хорошоокатанными ребрами и углами, 4- - ддеально окатанные гальки (эллипсондальной или сферической формы). 
ренах, содержащих много галек из гнейсов и рапакиви, происходит понижение коэффициентов окатанности за счет интенсивного раздробления валунов и галек в ходе. их транспортировки во льду.

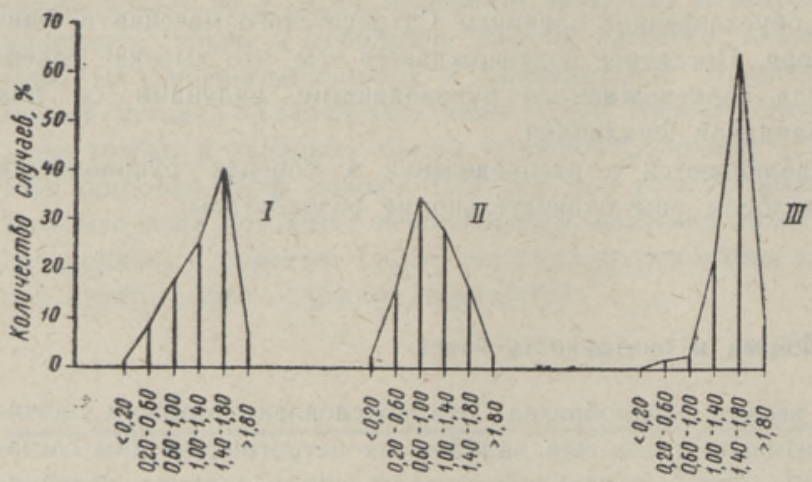

Фиг. 9. Коэффициенты окатанности галек карбонатных пород морен (по 151 анализу): I всей Эстонии; II - на ордовикских и силурийских коренных породах; III на девонских коренных породах.

козффичиенты окатанности

Несмотря на все эти возможные отклонения, все же хорошо прослеживается тенденция к увеличению коэффициента окатанности галек в моренах в сторону направления движения материкового льда, т. е. в сторону южных и юго-восточных районов республики. В табл. 4 приведены средние коэффициенты окатанности галек для различных регионов республики.

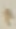

\begin{tabular}{l|c|c}
\hline \multirow{2}{*}{ Регионы } & \multicolumn{2}{|c}{ Породы } \\
\cline { 2 - 3 } & $\begin{array}{c}\text { карбо- } \\
\text { натные }\end{array}$ & $\begin{array}{c}\text { кристалли- } \\
\text { ческие }\end{array}$ \\
\hline 3ападные острова & 0,99 & 1,49 \\
С-3 Эстония & 0,90 & 1,32 \\
С-В Эстония & 0,94 & 1,49 \\
Ю-3 Эстония & 1,40 & 1,47 \\
Ю-В Эстония & 1,51 & 1,63
\end{tabular}

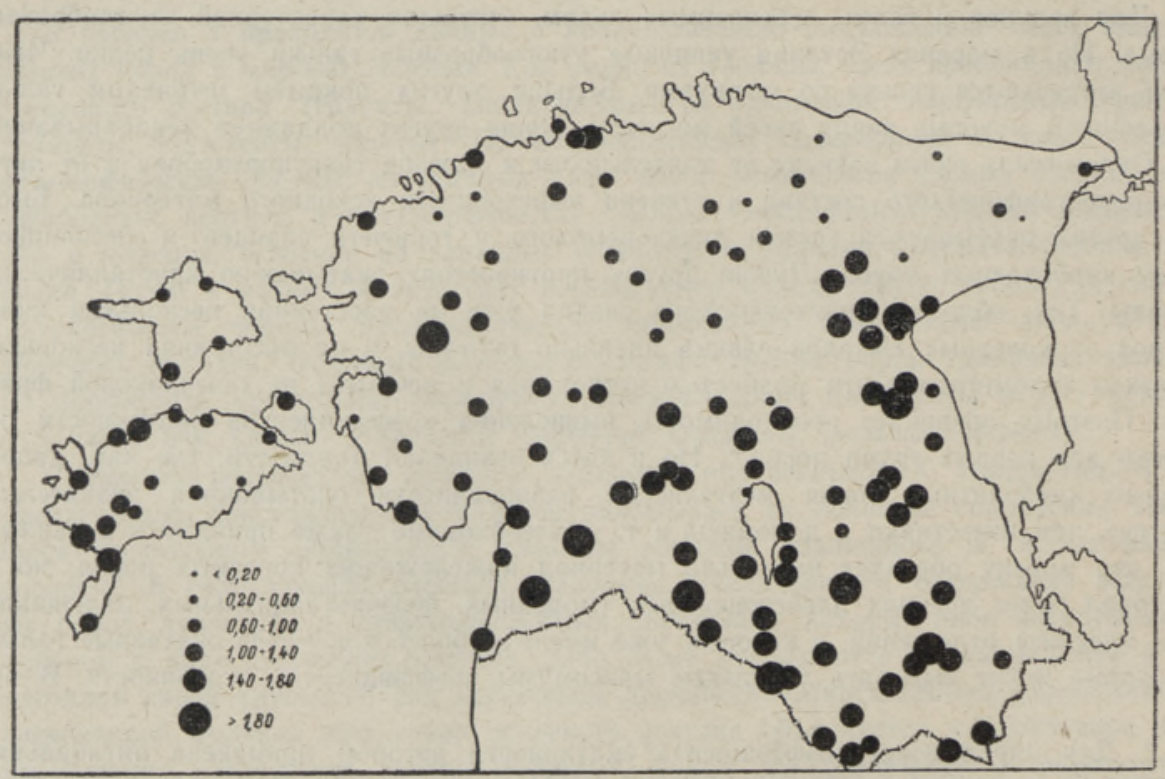

Фиг. 10. Коэффициенты окатанности галек карбонатных пород в моренах Эстонии. 
У карбонатных пород изменение окатанности наблюдается гораздо лучше, чем у кристаллических. Это вполне понятно, так как последние окатываются значительно медленнее карбонатных и на небольшой территории республики различия в окатанности выявляются не особенно четко.

В южной Эстонии почти совершенно отсутствуют морены со средней окатанностью галек карбонатных пород меньше величины 1,0. В то же время в северной Эстонии количество таких местонахождений превышает $50 \%$ (фиг. 9 и 10).

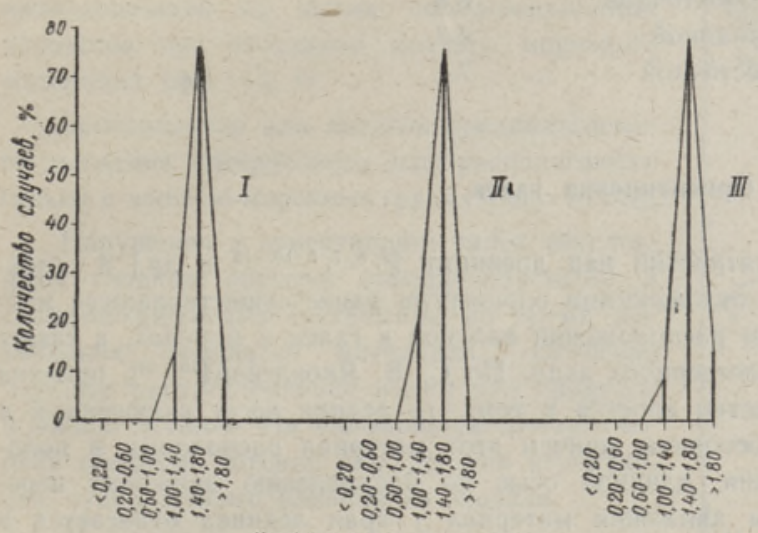

Фиг. 11. Коэффициенты окатанности галек кристаллическнх (магматических и метаморфических) пород морен (по 170 анализам): I - всей Эстонии; II - на ордовикских и силурийских коренных породах; III - на девонских коренных породах.

Козффичиенты окатанности

У·кристаллических пород, несмотря на небольшие различия в средних цифрах, также ясно выражена тенденция к возрастанию окатанности в сторону движения материкового льда (фиг. 11 и 12). В моренах южных районов республики совсем отсутствуют гальки кристаллических пород со средней окатанностью менее 1,2 , а галек со средней окатанностью более 1,6 имеется в $47,6 \%$ анализах против $26,7 \%$ в северной Эстонии. Интересен тот факт, что высоким коэффициентом окатанности

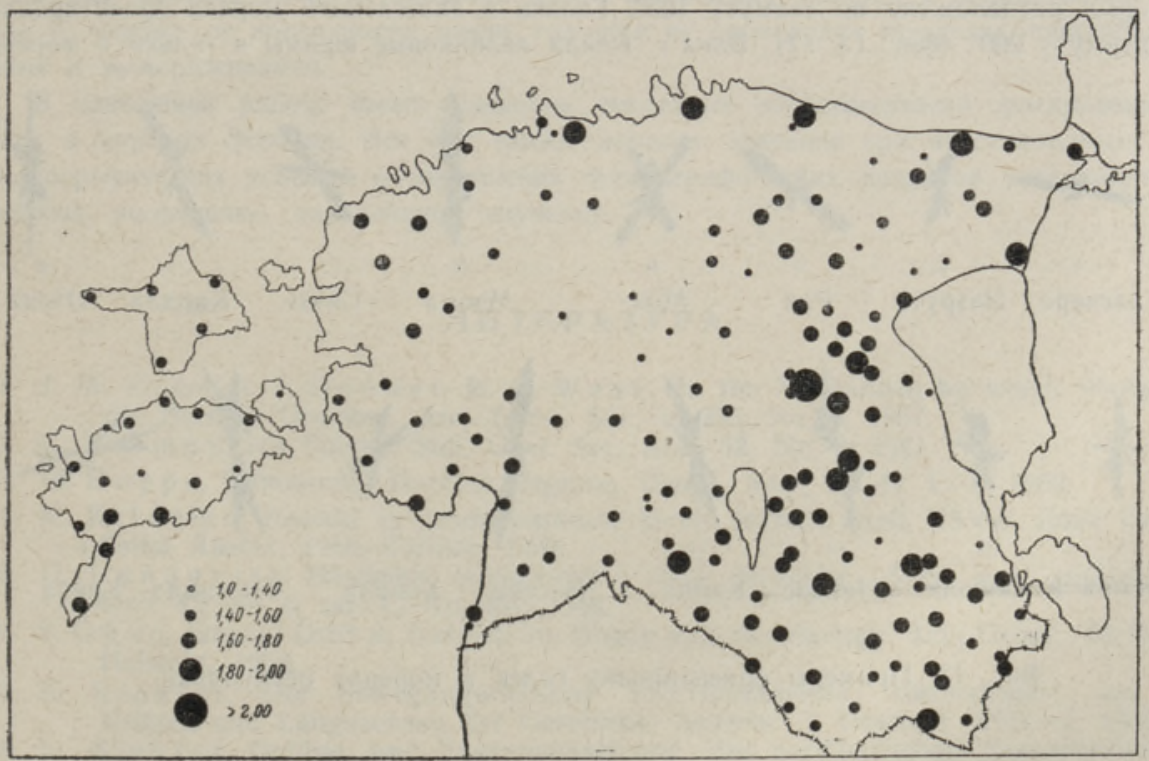

Фиг. 12. Коэффициенты окатанности галек кристаллических (магматических и метаморфических) пород в моренах Эстонии. 
обладают галькн в моренах перед глинтом и близ него. По всей вероятности, здесь происходило обогащение морены более древней хорошо окатанной морской галькой

В связи с сильным окатыванием валунов и галек происходит уменьшение среднего объема последних * и содержання в морене крупных валунов в направлении движения льда. Для иллюстрацин приведем средние объемы галек (в см³) для раэ личных регионов республики:

$\begin{array}{llr}\text { В северо-западной Эстонии } & 8,6 \\ \text { В северо-восточной } & \quad & 8,8 \\ \text { В юго-западной } & . & 6,3 \\ \text { В юго-восточной } & , & 7,1\end{array}$

\section{Ориентировка галек}

Исследования последних десятилетий над древними $[2,5,7,8,10-13$ и др.] и совре менными [3,6 и др.] ледннковыми отложениями опровергли ранее существовавшее мнение о хаотическом, беспорядочном расположении валунов и галек в моренах, а также зерен мелкозема и кристаллов глетчерного льда. По С. В. Яковлевой [10-13], причина упорядоченного расположения частиц кроется в том, что ледник несет включенный в него материал во взвешенном состоянии, причем этот материал расположен в положенки наименьшего сопротивления, длинной осью по направлению движения переносящей среды. С прекращением движения материал у края ледника отлагается в условиях постоянного подмерзания в том же положении, в каком он переносился. Но как показывают исследования [1], физические и механические основы ориентированного расположения частиц в морене требуют еще дальнейшего изучения.

Многочисленные анализы **, выполненные автором, также подтверждают ориентированное расположение галек. При этом наилучшие результаты были получены у морен, лежащих на равнинах или в пределах друмлиновых полей. Ориентировка галек здесь обычно совпадает с ориентировкой ледниковых шрамов и друмлинов или отличается от них незначительно (не больше $10^{\circ}$ ). Так, близ с. Кяйна (о. Хийумаа) на дне магистральной канавы наблюдаются ледниковые шрамы, большинство которых расположено по азимуту $192^{\circ}$. Гальки в залегающей морене ориентированы ло азимуту $200^{\circ}$ (фиг, 13,12 ). Близ г. Кейла ледниковые шрамы и гальки в моренах

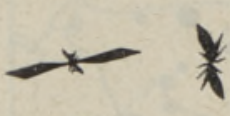

2

Каагвере Нээрути

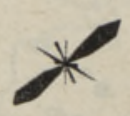

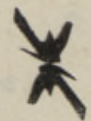

Mоэ

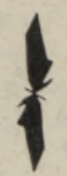

5

Мэома

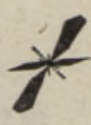

6

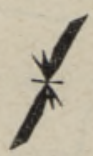

7

Кардла

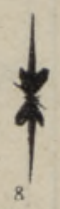

Отепя

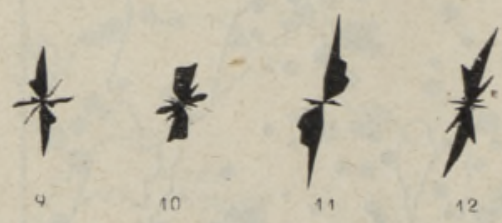

Руусмяэ Койккюла Ниназе Кяйна

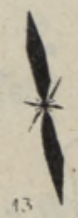

Рнстна

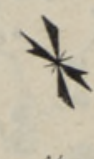

14

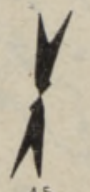

Тыстамаа Кийза

Фнг. 13. Примеры орнентировки галек в моренах республики.

* См. примечание на стр. 140 .

** Замеры ориентировки галек произведены в 179 обнаженнях. Всего выполнено 192 анализа. 
располагаюгся преимущественно по азимуту $180^{\circ}$. Подобные примеры можно привести из многих мест республики. О соотношении расположения друмлинов и галек в близлежащих моренах дает представление фиг. 14.

В холмистом рельефе (Отепя, Хаанья), где вытаивание морены происходило в основном в условиях мертвого льда, нередко нарушалась первичная ориентировка галек. Местами наблюдается также их переориентировка, происходившая во время солифлюкционных процессов при сползании мокрого моренногс материала (фиг. 13, 1 ).

Беспорядочно или поперек предполагаемого двнжения материкового льда располагаются гальки в конечно-моренных грядах (фиг. 13, 16).

Нарушения в ориентировке галек обусловлены главным образом оползнеподобными и солифлюкционными процессами во время вытаивания моренного материала. Особенно большое распространение имеют эти процессы в южной Эстонин. На маломощную донную морену северной Эстонии онн, по всей вероятности, существенного влияния не оказали.

Меньшее распространение имеют те отклонения ориентировки галек господствующего направления движения ледника, которые возникали при перевертывании галек в толще ледника или при перекатывании их подледниковыми и внутриледниковыми талыми водами [13], под влиянием древнего рельефа, благодаря

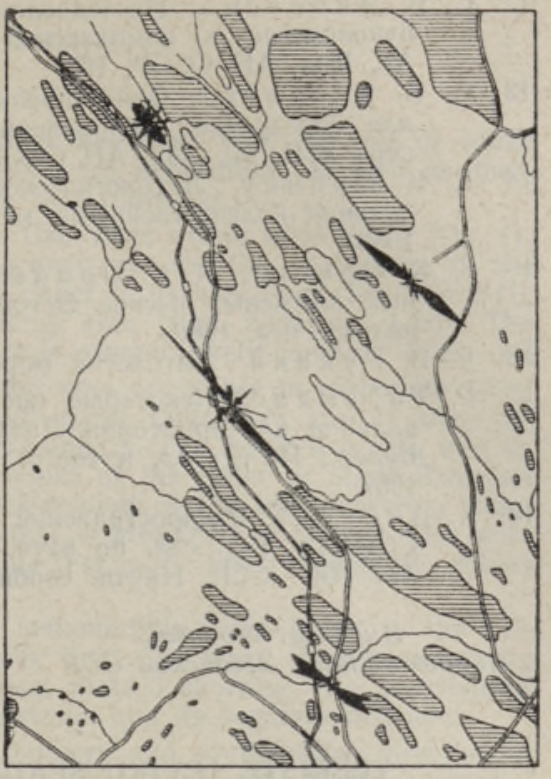

Фиг. 14.

Ориентировка галек в моренах Саадъярвеского друмлинового поля. процессам неотектоническнх движений и гляциотектоники, в результате пучения грунтов или пронизывания корнями деревьев $\left[{ }^{10},{ }^{16}\right]$. Последняя причнна легко устраняется путем проведения замеров в невыветрелой морене - глубже от поверхности земли, где уже не происходят процессы почвообразования и вымораживания.

В настоящей работе были освещены некоторые закономерности распределения галек в моренах Эстонии. Все они имеют немалое значение при восстановлении палеогеграфических условиї и разрешенин стратиграфических вопросов антропогена н требуют, несомненно, дальнейшего изучения.

\section{ЛИТЕРА Т У РА}

1. J. W. Glen, J. J. D on ner, R. G. West, On the Mechanism by which Stones in Till Become Oriented. Am. Journ. Sci., v. 255, No. 3, 1957.

2. C. Holmes, Till Fabric. Bull. Geol. Soc. Am., 52, No. 9, 1941

3. G. H o p p e, Hummocky Moraine Regions. Geogr. Ann., 34, H. 1-2, 1952.

4. K. Kild e mi a, Seoseid ja seaduspärasusi kivide levikus Eesti NSV-s. Eesti Geogr. Seltsi Aastar. 1958, Tallinn, 1959.

5. G. Lundqvist, Blockens orientering i olika jordarter. Sver. geol. undersökn., Årsb. 42, No. 6, ser. C, No. 497, 1948.

6. V. O k k o, Glacial Drift in Iceland, Its Origin and Morphology. Acta Geogr., 15, No. 1, Helsinki, 1956.

7. K. Richter, Die Bewegungsrichtung des Inlandeises, rekonstruiert aus den Kritzen und Längsachsen der Geschiebe. Zeitschr. f. Gesch. f. VIII-1, 1932.

8. K. Richter, Gefüge und Zusammensetzung des norddeutschen Jungmoränengebietes, Zeitschr. f. Gesch. f. IX, 1933.

9. H. Vi i ding, Eesti NSV rändkivide petrograafiast. LUS Aastar., kd. 48, Tartu, 1955. 
10. С. В Яковлев а, Исследование ледниковых валунов. В кн. Методическое руководство по изучению и геологической съемке четвертичных отложений, ч. II, Госгеолтехиздат, 1955.

11. С. В. Яковлева, Об упорядоченном расположении валунов в толщах основных морен. Мат. Всес. н.-и. геол, ин-та, Нов, сер., в. 9, Госгеолтехиздат, 1955.

12. С. В. Яковлев а, Исследованне ледниковых валунов. В кн.: Краткое полевое руководство по комплексной геологической съемке четвертичных отложений, М., Изд. АН СССР, 1957.

13. С. В. Яковлева, Ориентировка валунов в основных моренах и ее значение для определения направления движения ледников. Тр. Ком. по изуч. четв. пер., XIII, М., Изд. АН СССР, 1957.

14. К. К. О в и ку, Литологическое исследование морены последнего оледенения Эстонии количественными методами. Тр. Ин-та геол. АН ЭССР, III. Таллин, 1958.

15. К, К О р в и у, К. К. О р в и ку-мл., О распространении и литологии современных пляжевых песков Эстонин, В сб. Вопросы накопления тяжелых минералов, Рига, 1960.

16. Е. В. Рухин а, Литология моренных отложений. Изд. Ленингр. ун-та, 1960.

17. Р. Т арвид ас, Некоторые предварительные данные изучения кристаллических валунов на территории Литвы. Тр. Рег. сов. по изуч. четв. отл. Приб. и Белор., Ин-т геол. и геогр. АН Лит. ССР, Научн. сообщ., т. IV, Вильнюс, 1957.

18. Х, В и йдинг, Распространение и петрография эрратических валунов Эстонской CС. Т. Рег. сов. по изуч. четв. отл. Приб. и Белор., Ин-т геол. и геогр. АН Лінт. ССР, Научн. сообщ., т. IV, Вильнюс, 1957.

\author{
Ннститут геологии \\ Академии наук Эстонской ССР \\ Поступила в редакцию \\ 15. IV 1961
}

\title{
VEERISTE LEVIKU SEADUSPÄRASUSED EESTI MOREENIDES
}

\section{A. Raukas}

\section{Resümee}

Moreenide uurimiseks kasutati nn. mahumeetodit, mille abil määrati veeriste hulk ja orienteeritus moreenis, nende granulomeetriline ja petrograafiline koosseis, kuju ja ümardatus.

Veeriste hulk $1 \mathrm{~m}^{3}$ moreenis kōigub suurtes piirides (joon. 1), olles umbes $70 \%$-il analüüsidest 1000-15000 vahel. Pōhja-Eestis karbonaatsete kivimite avamusalal levivad moreenid on veeristerikkamad (joon. 2-II ja 4-II) kui Lõuna-Eestis devoni avamusalal levivad moreenid (joon. 2-III ja 4-III). Veeriste hulk ühe paljandi piires on võrdlemisi püsiv (tab, 1).

Põhja-Eestis karbonaatsel avamusalal levivad moreenid on rikkamad karbonaatsete (joon. 5-II) ja vaesemad kristalsete kivimite poolest (joonised 6-II ja 7), võrreldes devoni kivimitel lasuvate moreenidega (joonised 5-III, 6-III ja 7). Devoni kivimid PōhjaEesti moreenides harilikult puuduvad. Nende hulk Lõuna-Eesti moreenides on näidatud joonisel 8. Môningate kambriumi kivimitel lasuvate (klindiesiste) moreenide kivimiline koostis on toodud tabelis 2. Mida rohkem on moreenis kristalseid kivimeid, seda väiksem on veeriste koguhulk (joon. 3).

Moreeenis esinevate kristalsete kivimite peamisteks lähtealadeks on Lõuna-Soome ning Läänemere pōhi. Veeriste seas esinevad kivimitüübid happelistest kuni ultraaluselisteni, kusjuures erinevate kivimirümade jaotumisest kogu Eesti territooriumil ja tema erinevates rajoonides anna5 ülevaate tabel 3.

Veeriste ümardatus suureneb vabariigi louna- ja kagurajoonide suunas ning langeb kokku mandrijäà tōenäolise liikumise suunaga (joonised $9,10,11,12$ ja tab. 4). Lōunarajoonides on väiksem ka veeriste keskmine maht (tab. 5).

Veeriste orienteeritus mandrijää liikumise suunas on kõige selgem tasandikulistel ja voorestatud aladel, kus see langeb kokku jääkriimude ja voorte suunaga (joon. 14). Künklikel aladel (Otepää, Haanja), kus moreeni väljasulamisel suurt osa etendas surnud jää, on veeriste orienteeritus sageli rikutud ning kohati esineb isegi veeriste sekundaarset orienteeritust (joonis 13, 1). Otsmoreensetes vöödes orienteeritus puudub vöi veerised on orienteeritud risti mandrijää liikumıse suunale (joonis 13. 13-16). 


\section{REGULARITIES IN THE DISTRIBUTION OF PEBBLES IN THE TILLS OF ESTONIA}

\section{A. Raukas}

\section{Summary}

At the study of tills the so-called volume-method was used, with the help of which the amount and orientation of pebbles in the tills were determined, as well as their granulometric and petrographic composition, shape and rounding.

In a cubic metre of tills the amount of pebbles fluctuates within wide limits (fig. 1), from 1000 to 15000 in about 70 per cent of all the analyses. The tills distributed in the outcrop area of North-Estonian carbonate rocks are richer in pebbles (figs. 2-II and 4-II) than the tills of the South-Estonian Devonian outcrop area (figs, 2-III and 4-III). The amount of pebbles within one and the same exposure is comparatively constant (plate 1).

The tills of the North-Estonian carbonate outcrop area are richer in carbonate rocks (fig. 5-II) and poorer in igneous and metamorphic rocks (figs. 6-II and 7) than the tills distributed on Devonian rocks (figs. 5-III, 6-III and ?). The North-Estonian tills do not contain any Devonian rocks, as a rule. The amount of the latter in South-Estonian tills is shown in fig. 8. The composition of the rock-content of the tills overlying some Cambrian strata (in front of the North-Estonian Glint) is presented in plate 2. The more igneous and metamorphic rocks there are in a till, the less is the total amount of pebbles (fig. 3).

The main areas from where the igneous and metamorphic rocks found in the tills came are South Finland and the bottom of the Baltic Sea. The types of rocks occurring among the pebbles vary from acid to ultra-basic ones, plate 3 showing the distribution of various rock-groups throughout the territory of Estonia and its separate districts.

The rounding of the pebbles increases in the southern and southeastern direction of the Republic, coinciding with the probable direction of the movement of the continental ice (figs. 9, 10, 11, 12 and plate 4 ). In the southern districts the average volume of the pebbles is also smaller (plate 5).

The orientation of pebbles in the direction of the movement of the continental ice is best traced in level and drumlin areas, where it coincides with the direction of icescratches and drumlins (fig. 14). In hilly areas (Otepää, Haanja), where in the meltingout of the till a great part was performed by dead ice, the orientation of the pebbles is often spoiled, and in places even a secondary orientation of pebbles can be traced (fig. 13, 1). In the end-moraine zones the orientation is lacking, or the pebbles are arranged in perpendicular to the direction of the continental ice (fig. 13, 13-16).

\author{
Academy of Sciences of the Estonian S.S.R., \\ Institute of Geology
}

Received April 15th, 1961 